\title{
Therapeutic significance of hormone receptor positivity in patients with HER-2 positive breast cancer
}

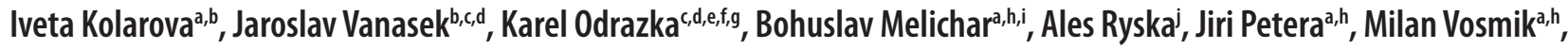 \\ Martin Dolezele,
}

Breast cancer with high expression of human epidermal growth factor receptor (HER)-2 represents a biologically and clinically heterogeneous group of neoplastic disorders. Importantly, hormone receptor expression has an effect on biological properties and affects the selection of therapies. On the basis of molecular genetics, four principal subtypes, including luminal A, luminal B, HER2-enriched (HER-2-E), and basal-like can be distinguished. Breast tumors characterized by HER-2 positivity and simultaneous expression of hormone receptors, triple positive breast cancers (TPBC) are of increasing interest owing to the unique biological characteristics associated with complex interactions between HER-2 and hormone receptor signaling pathways. Interactions between hormone receptors and HER-2 explain the decreased efficacy of hormonal therapy in comparison with HER-2-negative patients. The expression of estrogen receptors in HER-2 positive tumors may also be associated with resistance to anti-HER-2 treatment. Multiple available therapeutic options, including hormonal therapy, anti-HER-2 agents and cytotoxic drugs explain favorable prognosis of TPBC. Escalation and de-escalation therapeutic strategies that could result in lower toxicities are being investigated as well as combinations of anti-HER-2 agents with hormonal therapy, immunotherapy, cyclin dependent kinase $4 / 6$ and phosphatidyl inositol-3-kinase inhibitors. Distinction between subtypes of HER-2-positive breast cancer and treatment diversification may result in improved outcomes in TPBC. A response to neoadjuvant therapy may serve in the tailoring of therapy management.

Key words: breast cancer, estrogen receptor, HER-2

Received: July 30, 2019; Revised: October 30, 2019; Accepted: November 26, 2019; Available online: December 11, 2019 https://doi.org/10.5507/bp.2019.060

(c) 2019 The Authors. This is an open access article licensed under the Creative Commons Attribution License (https://creativecommons.org/licenses/by/4.0/).

${ }^{a}$ Department of Oncology and Radiotherapy, University Hospital Hradec Kralove, Czech Republic

${ }^{b}$ Faculty of Health Studies, Pardubice University, Pardubice, Czech Republic

'Oncology Centre, Multiscan, Pardubice, Czech Republic

${ }^{d}$ Department of Clinical and Radiation Oncology, Pardubice Hospital, Pardubice, Czech Republic

eDepartment of Oncology, First Faculty of Medicine, Charles University, Prague, Czech Republic

${ }^{f}$ Department of Radiotherapy and Oncology, Third Faculty of Medicine, Charles University, Prague, Czech Republic

IInstitute for Postgraduate Medical Education, Prague, Czech Republic

${ }^{h}$ Department of Oncology and Radiotherapy, Faculty of Medicine in Hradec Kralove, Charles University, Czech Republic

'Department of Oncology, Faculty of Medicine and Dentistry, Palacky University Olomouc and University Hospital, Olomouc, Czech Republic

'The Fingerland Department of Pathology, Charles University Medical Faculty and University Hospital Hradec Kralove, Czech Republic

Corresponding author: Martin Dolezel, e-mail:dolezelm@email.cz

\section{INTRODUCTION}

Breast cancer may serve as an example of a tumor whose biological characteristics impact in a fundamental manner on the presentation, behavior and therapy. The presence of hormone receptors (HR) and human epidermal growth factor receptor (HER)-2 is a principal factor determining the clinical management.

HER-2 is a member of a family of transmembrane tyrosine kinase receptors (together with HER-1 (EGFR), HER-3 and HER-4) and a universal partner for heterodimerization with other members of HER receptor family. The amplification of the gene c-erbB-2 resulting in overexpression or of HER-2 protein stimulates tumor growth, invasion and tumor cell survival by activation of several signaling pathways ${ }^{1}$.
HER-2 positive breast cancer is clinically and biologically heterogeneous disease. Based on gene expression profiling, four major molecular subtypes of HER-2 positive tumors have been identified, namely luminal A, luminal B, HER-2 enriched (HER2-E), and basal-like. The most common molecular subtype among them is the HER2-E (in 50-60 \% of cases) ( ref. $^{2}$ ).

Trastuzumab was the first HER-2-directed therapy. The unprecedented activity of trastuzumab paved the way for the introduction of other drugs targeting HER-2, including other monoclonal antibodies (pertuzumab), HER-2- tyrosine kinase inhibitors (lapatinib and neratinib) and antibody conjugates (e.g. trastuzumab emtansine; TDM-1). The medical therapy of HER-2 positive breast cancer is mostly based on concomitant or sequential combinations of HER2 targeting agents with cytotoxic or hormonal drugs. 
About three quarters of breast cancers express HR $\left(\right.$ ref. $^{3}$ ) while HER-2 amplification is present in only 12 $15 \%$ of cases. Simultaneous positivity of HR and HER-2 amplification is observed in about half of HER-2 positive breast cancer patients ${ }^{4,5}$.

The tumors positive for HER-2 as well as HR (HER 2+/ $\mathrm{HR}+$ ), termed triple positive breast cancer (TPBC) (ref. ${ }^{1,6,7}$ ) are characterized by unique biological properties resulting from complex interactions between HER-2 and estrogen receptor (ER) signaling pathways ${ }^{8-12}$.

The expression of ER and progesterone receptor (PR) is, in general, associated with better treatment outcome, at least in the short term. Overall survival (OS), disease-free survival (DFS) and progression-free survival (PFS) positively correlate with ER and PR expression ${ }^{13-15}$. However, although the 5-year relapse rate is higher in ER negative tumors, late relapses are more common in ER-positive tumors, sometimes decades after diagnosis ${ }^{12,16}$.

In ER positive luminal tumors, preclinical as well as clinical data demonstrate intensive interactions between signaling pathways stimulated by ER engagement and HER-2 amplification.

It has been demonstrated that activation of the ER pathway may be one of the mechanisms of resistance to anti-HER-2 therapy and that TPBC tumors frequently belong to the luminal molecular subtype ${ }^{11}$. The administration of trastuzumab improved OS in both luminal molecular subtypes in two large adjuvant trials (NSABP B31 and N9831) (ref. ${ }^{17,18}$ ). In patients with basal-like subtype, NSABP B31 has demonstrated an OS benefit of trastuzumab, but an OS benefit in these patients was not evident in the N9831trial.

In the treatment of TPBC anti-HER-2 therapy has to be combined with cytotoxic and hormonal agents ${ }^{9,10}$ Patients with high HER-2 positivity have statistically significantly lower HR expression compared to patients with lower HER-2 positivity resulting in lower efficacy of hormonal therapy compared to patients with HR-positive, HER-2 negative tumors ${ }^{5}$. On the other hand, ER positivity may be associated with the resistance to anti-HER-2 therapy ${ }^{5,19}$.

\section{Short-term survival in patients with HR-positive/HER-2- positive tumors}

A recently published study based on SEER registry analyzing the 4-year breast cancer-specific survival (BCSS) of 196094 patients treated between 2010 and 2013 according to tumor subtypes as well as clinical and demographic parameters demonstrated that TPBC patients had 4-year BCSS slightly lower compared to patients with HRpositive, HER-2 negative tumors ( $92.5 \%$ vs $90.3 \%$ ), with the survival rates in patients with HR-negative, HER-2positive and triple negative patients being $82.7 \%$ and 77.0 $\%$, respectively ${ }^{20}$. The stage was the strongest determinant of survival in this study, and 4-year BCSS in patients with stage I tumor was above $95 \%$ regardless of the subtype. Among patients with stage IV tumors, highest survival rates were noted in TPBC, even after correction for clinical and demographic factors.

\section{Long-term survival in HR-positive patients}

Colleoni et al. evaluated late relapse in patients with HR-positive tumors treated with adjuvant therapy between 1978 and 1985, i.e. at the time when HER-2 positivity was not evaluated, with a median follow up of 24 years $^{12}$. Favorable outcome was noted in patients with ER-positive compared to ER-negative tumors during the 5 years after diagnosis, with a higher incidence of late relapses. The risk of relapse for tumors expressing ER was significantly lower during the first 5 years $(9.9 \% v 11.5 \% ; P=0.01)$. In the subsequent period, the risk of recurrence was higher for ER-positive compared to ER-negative tumors ( 5 to 10 years: $5.4 \%$ v $3.3 \%$; 10 to 15 years: $2.9 \% v 1.3 \% ; 15$ to 20 years: $2.8 \% \vee 1.2 \%$; and 20 to 25 years: $1.3 \% \vee 1.4 \%$; $P<0.001)$. The survival curves of patients with ER-positive and ER-negative tumors cross over and hazard ratio of OS, DFS and BCSS change during the course of the time. Patients with ER-positive tumors have a higher risk of relapse, including distant metastases 5 to 25 years after diagnosis, supporting the need for long-term clinical follow-up.

\section{Long term survival in patients with HR-positive/HER-2- positive breast cancer}

A prospective study evaluating the effect of HR status in 3394 stage I - III patients treated in National Comprehensive Cancer Network (NCCN) centers demonstrated that patients with HR-negative, HER-2-positive tumors have a significantly higher risk of early, but not late death compared to TPBC. The hazard ratio for OS during the first two years after diagnosis was 1.92 , with 95\% confidence intervals $(\mathrm{CI}) 1.28$ - $2.86(P=0.002)$, hazard ratio 2 to 5 years after diagnosis was 1.55 (95\% CI 1.19 to $2.00, P=0.001$ ), and hazard ratio after 5 years from diagnosis was $0.81(95 \% \mathrm{CI} 0.55$ to $1.19, P=0.285)\left(\right.$ ref. $\left.^{21}\right)$.

The association of long-term outcome with molecular subtype was analyzed in a study evaluating HER-2-positive patients treated in the adjuvant setting demonstrating that at 10 years the relapse-free survival (RFS) is best in patients with luminal A molecular subtype (89.8\%), followed by luminal B (82.3\%), HER2-enriched (76.8\%) and basal-like (74.19\%) (ref. ${ }^{22}$ ). This study confirmed the difference in the timing of relapse between HR-positive, HER-2-positive and HR-negative, HER-2-positive tumors in patients treated with trastuzumab and chemotherapy. The relapse rate during the initial 5 years was higher in HR-negative, HER-2-positive patients in comparison with TPBC (RFS hazard ratio $0.65,95 \%$ CI 0.56-0.77, $P<0.001$ ), but this difference disappeared during the subsequent years (RFS hazard ratio $1.32,95 \%$ CI $0.93-1.88$, $P=0.12$ ).

A potential tumor-promoting synergism of stimulating both ER and HER-2 signaling pathways in TPBC may be offset by a wide range of therapeutic targets, including ER and HER-2 which may contribute to better survival in patients with advanced disease. The introduction of dual HER-2 blockade with the combination of trastuzumab, pertuzumab and chemotherapy has changed the therapeutic landscape by reaching a landmark median survival of almost 5 years, almost two years longer than would be 
expected in the pre-pertuzumab era ${ }^{23}$. Trastuzumab emtansine that combines trastuzumab with a cytotoxic agent represents another therapeutic option. These drugs can be administered in simultaneous or sequential combination or different lines of therapy, including the combinations with hormonal agents. However, prospective data on the combinations of anti-HER-2 therapies with hormonal drugs are currently limited.

\section{The significance of HR expression in TPBC}

As outlined above, it appears that some HER-2 positive, HR-positive tumors, specifically tumors with high ER expression are characterized by biological behavior of luminal tumor with favorable prognosis during the initial years after diagnosis, but a relatively high incidence of late relapses, putting the efficacy and importance of antiHER-2 therapy into question ${ }^{24}$.

The significance of the extent of hormone dependence on the behavior of TPBC is demonstrated by the results of a retrospective analysis of patients treated with adjuvant chemotherapy alone or in combination with trastuzumab. The administration of trastuzumab resulted in improved RFS as well as BCCS in all subgroups. However, in patients with tumors exhibiting more than $30 \%$ of HRpositive cells (and even more in patients with tumors demonstrating more than $50 \%$ of HR-positive cells), the differences in survival were not significant. The pattern of relapse was different in patients with tumors exhibiting more than $50 \%$ of HR-positive cells with a low risk of relapse during the first 5 years, with a subsequent rise in the relapse rate later, and a limited effect of trastuzumab administration. Multivariate analysis of RFS demonstrated that the benefit of trastuzumab treatment is limited to tumors with $\leq 50 \%$ ER-positive cells ${ }^{8}$.

These conclusions are supported by a secondary analysis of the HERA trial that demonstrated significantly lower benefit from adjuvant trastuzumab in patients with ER-positive tumors and low level of HER-2 amplification (low HER-2/CEP17 ratio determined by fluorescent in situ hybridization) compared to patients with tumors characterized by the high level of HER-2 amplification and low expression of hormone receptors determined immunohistochemically. Patients with ER-positive tumors and low HER-2 amplification (ratio 2-5) or higher ESR1 expression show lower benefit from adjuvant trastuzumab administered after chemotherapy. It may be hypothesized that in some cases of TPBC, tumor growth may be more dependent on signaling pathways characteristic for luminal tumors rather than HER-2-related mechanisms ${ }^{25}$.

\section{Implications for therapy in treatment settings}

A number of trials studied the intensification of neoadjuvant therapy aiming at increasing the pathological complete response ( $\mathrm{pCR}$ ) rate or improving survival. The results of several neoadjuvant studies have demonstrated that independent of the anti-HER-2 therapy regimen the pCR rate is markedly lower in TPBC compared to patients with HR-negative, HER-2-positive tumors. Interestingly, the low pCR rate does not affect a generally favorable prognosis of TPBC $\left(\right.$ ref. $\left.^{24}\right)$, and it may be speculated whether the administration of neoadjuvant treatment comprising chemotherapy in early TPBC with favorable prognosis is not an overtreatment ${ }^{26}$.

In the neoadjuvant setting dual anti-HER-2 blockade was tested in combination with hormonal therapy in the absence of chemotherapy with pCR rate reaching 20-30\% (ref. ${ }^{2,27}$ ).In the ADAPT trial T-DM1 administered with or without hormonal therapy (aromatase inhibitors) was compared with the combination of trastuzumab with hormonal therapy. T-DM1 resulted in pCR rate above $41 \%$ independent of the administration of hormonal therapy, while the pCR rate for the combination of trastuzumab with hormonal therapy was substantially lower (15\%) (ref. $\left.{ }^{28}\right)$.

In the GeparQuinto trial prolonged administration of lapatinib in patients with HR-positive tumors in combination with standard medical therapy that included anthracyclines and taxanes as well as hormonal agents according to local guidelines followed by adjuvant trastuzumab for 12 months resulted in significantly improved OS compared with adjuvant trastuzumab (hazard ratio 0.32 ; $P=0.019$ ). The neoadjuvant administration of EGFR/ HER-2 inhibitor lapatinib followed by adjuvant trastuzumab may achieve more effective inhibition of growth signaling in endocrine-dependent tumor cells, resulting in improved efficacy in TPBC (ref. ${ }^{29,30}$ ).

In the PERELISA trial a repeat biopsy was performed after 2 weeks of neoadjuvant letrozole. In patients with a decrease of Ki67 expression by more than 20\%, letrozole was continued in combination with trastuzumab and pertuzumab. In remaining patients, weekly paclitaxel in combination with trastuzumab and pertuzumab was administered. The pCR rate in patients with decreased Ki67 treated with trastuzumab, pertuzumab and letrozole was $20.5 \%$ (ref. $^{31}$ ).

Current standard of medical therapy in TPBC consists of anti-HER-2 agents combined with hormonal, and, with the exception of tumors smaller than $0.5 \mathrm{~cm}$, also cytotoxic drugs. Hormonal therapy is administered sequentially to chemotherapy and concomitantly with maintenance trastuzumab?

The results of SOFT and TEXT trials investigating ovarian function suppression (OFS) as part of adjuvant endocrine therapy indicate the higher benefit of OFS in TPBC compared to patients with HR-positive, HER-2negative tumors that persists after therapy and is present regardless of anti-HER-2 treatment ${ }^{32}$.

The data of Adjuvant Lapatinib and/or Trastuzumab Treatment Optimization trial also indicate that patients with amenorrhea during therapy have better outcome ${ }^{33}$. However, an optimal regimen of oral endocrine treatment with OFS in TPBC patients has not yet been determined.

The phase III Katherine trial investigated the efficacy of adjuvant administration of T-DM1 in patients who did not achieve pCR after neoadjuvant chemotherapy with trastuzumab. The patients with residual disease in surgical specimens were randomized between T-DM1 or trastuzumab. A significant benefit in invasive disease-free survival at 3 years for T-DM1 $(88.3 \%$ vs. $77 \%, P<0.001)$ was observed regardless of HR expression ${ }^{34}$. 
Table 1. HER2 positive breast cancer trials - adjuvant setting.

\begin{tabular}{|c|c|c|c|c|c|}
\hline Clinical trial & Therapy & Control & Design & Results & Ref. \\
\hline $\begin{array}{l}\text { Katherine } \\
\text { A Randomized, Multicenter, Open-Label } \\
\text { Phase III Study to Evaluate the Efficacy } \\
\text { and Safety of Trastuzumab Emtansine } \\
\text { Versus Trastuzumab as Adjuvant Therapy } \\
\text { for Patients With HER2-Positive Primary } \\
\text { Breast Cancer Who Have Residual Tumor } \\
\text { Present Pathologically in the Breast } \\
\text { or Axillary Lymph Nodes Following } \\
\text { Preoperative Therapy }\end{array}$ & $\begin{array}{l}\text { trastuzumab } \\
\text { emtansine } \\
\text { every } 3 \text { weeks, } \\
14 \text { cycles }\end{array}$ & $\begin{array}{l}\text { trastuzumab } \\
\text { every } 3 \text { weeks, } \\
14 \text { cycles }\end{array}$ & $\begin{array}{l}\text { patients without } \\
\text { pCR } \\
\text { after neoadjuvant } \\
\text { chemotherapy } \\
+ \text { trastuzumab }\end{array}$ & $\begin{array}{l}3 \text {-year iDFS } \\
88.3 \% \text { vs. } 77 \% \\
P<0.001\end{array}$ & 34 \\
\hline $\begin{array}{l}\text { ExteNET } \\
\text { A Randomized, Double-Blind, Placebo- } \\
\text { Controlled } \\
\text { Trial Of Neratinib (HKI-272) After } \\
\text { Trastuzumab } \\
\text { In Women With Early-Stage HER-2/Neu } \\
\text { Overexpressed/Amplified Breast Cancer }\end{array}$ & $\begin{array}{l}\text { neratinib } \\
1 \text { year }\end{array}$ & placebo & $\begin{array}{l}12 \text { months of adju- } \\
\text { vant trastuzumab } \\
+ \text { - neratinib } 1 \text { year }\end{array}$ & $\begin{array}{l}\text { 5-year iDFS } \\
\text { HR+ patients: } 91,2 \% \\
\text { vs. } 86,8 \% \\
\text { hazard ratio } 0.60 \\
95 \% \text { CI } 0.43-0.83 \\
P=0.002\end{array}$ & 35 \\
\hline $\begin{array}{l}\text { APT } \\
\text { A Phase II Trial of Adjuvant Paclitaxel and } \\
\text { Trastuzumab for Node-Negative HER2- } \\
\text { Positive Breast Cancer }\end{array}$ & $\begin{array}{l}12 \times \text { weekly } \\
\text { paclitaxel + } \\
1 \text { year } \\
\text { trastuzumab }\end{array}$ & 0 & a single arm trial & $\begin{array}{l}\text { 7-year DFS } \\
\text { HR+ patients: } \\
94.6 \% \\
\text { (95\% CI } 91.8-97.5) \\
\text { HR- patients: } 90.7 \% \\
\text { (95\% CI } 84.6-97.2) \\
\end{array}$ & 36 \\
\hline
\end{tabular}

iDFS - invasive disease free survival

DFS - disease free interval

Adjuvant dual blockade was tested in the EXTNET phase III placebo controlled trial investigating the effect of one year treatment with neratinib after standard 12 months of adjuvant trastuzumab ${ }^{35}$. A significant improvement of invasive disease-free survival at 5 years was observed in patients with tumors expressing hormone receptors (hazard ratio $0.60,95 \% \mathrm{CI} 0.43-0.83, P=0.002$ ).

APT trial evaluated the efficacy of a non-anthracyclin adjuvant chemotherapy. Patients with tumors $<3 \mathrm{~cm}$ and no axillary involvement were treated with 12 weekly doses of paclitaxel with trastuzumab administered for a year. Seven-year DFS in the whole cohort was 93.3\% (95\% CI 90.4-96.2\%), 94.6\% (95\% CI 91.8-97.5\%) in patients with HR-positive tumors, and 90.7\% (95\% CI 84.6-97.2\%) in patients with HR negativity. This regimen is currently considered as an effective treatment in patients with small tumor expressing both HR and HER-2 (ref. ${ }^{36}$ ). The results of selected clinical trials investigating adjuvant therapy of HER-2 positive breast cancer are presented in Table 1.

Patients with advanced TPBC were studied in TAnDEM, EGF30008 and eLEcTRA trials that demonstrated a significant prolongation of PFS with the addition of anti-HER-2 therapy to hormonal treatment, but an improvement of OS did not reach statistical significance ${ }^{37-40}$.

Retrospective analyses indicate that the combination of hormonal therapy with anti-HER-2 treatment may improve outcomes ${ }^{41}$. American Society of Clinical Oncology (ASCO) and European Society for Medical Oncology (ESMO) guidelines consider justified the addition of endocrine therapy as maintenance in patients with metastatic TPBC ( ref. $^{10,42}$ ).

A PFS benefit of the combination of dual HER-2 blockade (pertuzumab and trastuzumab) and aromatase inhibitor in patients with metastatic TPBC has been demonstrated in the PERTAIN trial with median PFS in the experimental arm of 18.9 months compared to 15.8 months in the control arm (hazard ratio 0.65 ; $95 \% \mathrm{CI}$ 0.48-0.89; $\mathrm{P}=0.007)\left(\right.$ ref. $\left.^{43}\right)$. In the ALTERNATIVE trial patients who progressed during neoadjuvant or adjuvant treatment with trastuzumab and chemotherapy were treated with an aromatase inhibitor and randomized into three treatment arms of trastuzumab monotherapy, lapatinib monotherapy and the combination of trastuzumab and lapatinib $^{44}$. An improvement of PFS was observed for dual blockade compared to either agent alone (median PFS 11 months compared to 8.3 months for lapatinib and 5.7 months for trastuzumab). The results of selected clinical trials investigating the treatment of advanced TPBC are presented in Table 2.

\section{The significance of tumor infiltrating lymphocytes (TIL)}

The presence of TIL is one of the most important predictors of response to therapy and long-term survival in patients with breast cancer ${ }^{45}$. In patients with HER-2positive breast cancer the presence of TIL is associated with better survival in both early disease ${ }^{46-48}$ and in metastatic setting ${ }^{49}$.

The presence of TIL is predictive of pCR after antiHER2 neoadjuvant treatment independently of other 
Table 2. Triple positive breast cancer trials (advanced setting).

\begin{tabular}{|c|c|c|c|c|}
\hline Clinical Trial & Therapy & Control & Results & Ref. \\
\hline $\begin{array}{l}\text { TAnDEM } \\
\text { Trastuzumab Plus Anastrozole Versus Anastrozole } \\
\text { Alone for the Treatment of Postmenopausal Women } \\
\text { With Human Epidermal Growth Factor Receptor } \\
\text { 2-Positive, Hormone Receptor-Positive Metastatic } \\
\text { Breast Cancer: Results From the Randomized Phase } \\
\text { III TAnDEM Study }\end{array}$ & $\begin{array}{l}\text { trastuzumab + } \\
\text { anastrozol }\end{array}$ & anastrozol & $\begin{array}{l}\text { median PFS } 3.8 \text { months } v s \text {. } \\
5.6 \text { months } \\
P=0.006\end{array}$ & 37 \\
\hline $\begin{array}{l}\text { EGF30008 } \\
\text { A Randomized, Double-Blind, Placebo-Controlled, } \\
\text { Multicenter, Phase III Study Comparing GW572016 } \\
\text { and Letrozole Versus Letrozole in Subjects With } \\
\text { Estrogen/Progesterone Receptor-Positive Advanced or } \\
\text { Metastatic Breast Cancer }\end{array}$ & $\begin{array}{l}\text { lapatinib + } \\
\text { letrozole }\end{array}$ & letrozole & $\begin{array}{l}\text { PFS } 8.2 \text { vs. } 3.0 \text { months } \\
\text { hazard ratio } 0.71 ; 95 \% \\
\text { CI, } 0.53-0.96 \\
P=0.019\end{array}$ & 38,39 \\
\hline $\begin{array}{l}\text { eLEcTRA } \\
\text { An Open Label, Randomized Comparison of Femara }{ }^{\circledR} \\
\text { 2.5mg Once Daily With or Without Weekly Herceptin } \\
\text { Until Disease Progression as First-line Treatment } \\
\text { in Postmenopausal Women With Advanced Breast } \\
\text { Cancer }\end{array}$ & $\begin{array}{l}\text { trastuzumab + } \\
\text { letrozole }\end{array}$ & letr & $\begin{array}{l}\text { median TTP } 14.1 \\
\text { vs. } 3.3 \text { months } \\
\text { hazard ratio } 0.67 ; 95 \% \\
\text { CI } 0.35-1.29 \\
P=0.23\end{array}$ & 40 \\
\hline $\begin{array}{l}\text { PERTAIN } \\
\text { A randomized, two-arm, open-label, multicenter phase } \\
\text { II trial assessing the efficacy and safety of pertuzumab } \\
\text { given in combination with trastuzumab plus an aroma- } \\
\text { tase inhibitor in first-line patients with HER2-positive } \\
\text { and hormone receptor-positive metastatic or locally } \\
\text { advanced breast cancer }\end{array}$ & $\begin{array}{l}\text { pertuzumab + } \\
\text { trastuzumab } \\
+ \text { AI }\end{array}$ & $\begin{array}{l}\text { trastuzumab } \\
+\mathrm{AI}\end{array}$ & $\begin{array}{l}\text { PFS } 18.9 \text { vs. } 15.8 \text { months } \\
\text { hazard ratio } 0.65 ; 95 \% \\
\text { CI } 0.48-0.89 \\
P=0.007\end{array}$ & 43 \\
\hline $\begin{array}{l}\text { ALTERNATIVE } \\
\text { progression on trastuzumab } \\
\text { Phase III, Randomized Study of Dual Human } \\
\text { Epidermal Growth Factor Receptor } 2 \text { (HER2) } \\
\text { Blockade With Lapatinib Plus Trastuzumab in } \\
\text { Combination With an Aromatase Inhibitor in } \\
\text { Postmenopausal Women With HER2-Positive, } \\
\text { Hormone Receptor-Positive Metastatic Breast } \\
\text { Cancer: ALTERNATIVE }\end{array}$ & $\begin{array}{l}\text { lapatinib }(\mathrm{L}) \\
+ \text { trastuzumab } \\
(\mathrm{T})+\mathrm{AI}\end{array}$ & $\begin{array}{l}\text { lapatinib + } \\
\text { AI }(\mathrm{L}+\mathrm{AI}) \\
\text { vs. } \\
\text { trastuzumab } \\
+\mathrm{AI}(\mathrm{T}+\mathrm{AI})\end{array}$ & $\begin{array}{l}\text { median PFS } \mathrm{L}+\mathrm{T}+\mathrm{AI} \\
\text { vs. } \mathrm{T}+\mathrm{AI}: 11.0 \text { vs. } 5.7 \text { months } \\
\text { hazard ratio } 0.62,95 \% \\
\text { CI } 0.45,0.88 \\
P=0.0064 \\
\text { median PFS L+AI } \\
\text { vs. } \mathrm{T}+\mathrm{AI}: 8.3 \text { vs. } 5.7 \text { months } \\
\text { hazard ratio } 0.71,95 \% \\
\text { CI } 0.51,0.98 \\
P=0.0361\end{array}$ & 44 \\
\hline
\end{tabular}

PFS - progression free survival

AI - aromatase inhibitors

TTP - time to tumor progression

clinical and pathological parameters. The presence of TIL in HER-2-positive tumors may also predict the response of anti-PD1 immunotherapy as indicated by the results of the phase Ib/II PANACEA trial that investigated the efficacy of pembrolizumab in trastuzumab-resistant metastatic breast cancer ${ }^{50}$. In HER-2-positive tumor TIL counts are higher in non-luminal compared to luminal molecular subtypes as indicated in the analyses of CHERLOB (ref. ${ }^{51}$ ) and PAMELA (ref. ${ }^{52}$ ) trials that also demonstrated a positive correlation between TIL counts and pCR.

\section{CDK4/6 inhibitors}

Cyclin dependent kinase (CDK) 4/6 inhibitors currently represent an effective therapy of ER-positive, HER-2 negative breast cancer ${ }^{53}$. Regimens of CDK4/6 inhibitors and hormonal agents have also been tested in combination with anti-HER-2 therapy in TPBC.
In the preliminary analysis of the PATRICIA (SOLTI 13-03) trial that tested the addition of palbociclib to trastuzumab with or without letrozole in patients after 2-4 lines of therapy a longer PFS was noted in patients with luminal tumors (defined by PAM50) compared to patients with non-luminal tumors (median 12.4 vs 4.1 months, adjusted hazard ratio $=0.37 ; P=0.052)\left(\right.$ ref. $\left.^{54}\right)$. Palbociclib in combination with trastuzumab may represent a safe and effective therapy in previously treated patients with advanced HER-2 positive breast cancer, specifically TPBC. The detection of non-luminal subtypes using PAM50 may aid in identifying the patients who are unlikely to benefit from this therapy, regardless of hormone receptor status.

In the phase II NA-PHER trial the administration of neoadjuvant therapy regimen combining trastuzumab, pertuzumab, palbociclib and fulvestrant (i.e. not containing cytotoxic drugs) in patients with TPBC resulted 
in the significant decrease of Ki67 after both 2 weeks and 16 weeks (at surgery). Ki67 expression significantly decreased during therapy. Complete response was observed in $50 \%$ of the patients, and the pCR rate was $27 \%$, indicating that the combined strategy aiming at ER and HER-2 may be an effective approach that avoids the use of cytotoxic agents in TPBC ( ref. $^{55}$ ).

\section{PI3K and mTOR inhibitors}

The dysregulation of phosphatidyl-inositol-3-kinase (PI3K) and mammalian target of rapamycin (mTOR) signaling pathways may represent an important mechanism of trastuzumab resistance ${ }^{56}$.

The trials investigating the utilization of the mTOR inhibitor everolimus in HER-2 positive breast cancer (BOLERO-1 and BOLERO-3) brought negative results. Search of predictive biomarkers of response to everolimus indicated that mutation in the PI3K pathway may predict the response to everolimus ${ }^{57}$. A number of PI3K pathway inhibitors are currently tested in patients with HER-2 positive tumors, but none of these compounds has been registered so far and thus cannot be used outside of clinical trials ${ }^{58,59}$.

\section{CONCLUSION}

The distinction between subtypes of HER-2-positive breast cancer may improve prognostication and leads to diversification of therapeutic options. The unique biology of TPBC resulting from interactions between HER-2 and ER is currently being investigated in numerous clinical trials. The efficacy of hormonal agents, anti-HER-2 therapy and cytotoxic drugs in TPBC is, in general, associated with favorable prognosis, and similarly to other luminal tumors, the prognosis during the initial years is favorable while there are more frequent late relapses.

While the distinction between ER-positive and ERnegative HER-2-positive tumors has in the current guidelines only limited therapeutic implications, strategies investigating hormonal therapy in TPBC are being intensively studied in clinical trials of escalation as well of deescalation of treatment in selected subgroups. An early evaluation of response to neoadjuvant therapy may represent one approach of tailoring the intensity of therapy with the aim of reducing toxicity. Laboratory methods are an indispensable part of patient management in the era of targeted therapies ${ }^{60}$, and molecular testing using multigene platforms is becoming an essential part of therapeutic decisions.

\section{Search strategy and selection criteria:}

In this review, we have evaluated studies on the role of the hormone dependency in patients with HER2-positive breast cancer. Scientific articles from 1990 to 2019 were searched using the PubMed and Web of Science databases. All searches were up to date as of June 2019. The search terms used included „breast cancer”, „triple positive”, „HER-2 positivity”, „,estrogen receptor”, „progesterone receptor”, „hormonal therapy“, „anti-HER-2 therapy“, „prognosis“ and „survival”. Only English language papers were reviewed.

Author contributions: JV, BM: manuscript writing; KO, $\mathrm{AR}, \mathrm{LD}, \mathrm{MV}$ and MD: manuscript revision.IK: literature search, manuscript writing and final approval; AR: written English correction, MD, JP, MV: critical reading, final approval.

Conflict of interest statement: The authors state that there are no conflicts of interest regarding the publication of this article.

\section{REFERENCES}

1. Giuliano M, Trivedi MV, Schiff R. Bidirectional crosstalk between the estrogen receptor and human epidermal growth factor receptor 2 signaling pathways in breast cancer: molecular basis and clinical implications. Breast Care 2013;8(4):256-62.

2. Llombart-Cussac A, Cortés J, Paré L, Galván P, Bermejo B, Martínez N Vidal M, Pernas S, López R, Muñoz M, Nuciforo P, Morales S, Oliveira $M$, de la Peña L, Peláez A, Prat A. HER2-enriched subtype as a predictor of pathological complete response following trastuzumab and lapatinib without chemotherapy in early-stage HER2-positive breast cancer (PAMELA): an open-label, single-group, multicentre, phase 2 trial. Lancet Oncol 2017;18(4):545-54.

3. Osborne CK, Schiff R. Mechanisms of endocrine resistance in breast cancer. Annu Rev Med 2011;62:233-47.

4. Lal P, Tan LK, Chen B. Correlation of HER-2 status with estrogen and progesterone receptors and histologic features in 3655 invasive breast carcinomas. Am J Clin Pathol 2005;123(4):541-6.

5. Konecny G, Pauletti G, Pegram M, Untch M, Dandekar S, Aguilar Z, Wilson C, Rong HM, Bauerfeind I, Felber M, Wang HJ, Beryt M, Seshadri R, Hepp H, Slamon DJ. Quantitative association between HER-2/neu and steroid hormone receptors in hormone receptorpositive primary breast cancer. J Natl Cancer Inst 2003;95(2):142-53.

6. Wang YC, Morrison G, Gillihan R, Guo J, Ward RM, Fu X, Botero MF, Healy NA, Hilsenbeck SG, Phillips GL, Chamness GC, Rimawi MF, Osborne CK, Schiff R. Different mechanisms for resistance to trastuzumab versus lapatinib in HER2-positive breast cancers role of estrogen receptor and HER2 reactivation. Breast Cancer Res 2011;13(6):R121.

7. Giuliano M, Hu H, Wang YC, Fu X, Nardone A, Herrera S, Mao S, Contreras A, Gutierrez C, Wang T, Hilsenbeck SG, De Angelis C, Wang NJ, Heiser LM, Gray JW, Lopez-Tarruella S, Pavlick AC, Trivedi MV, Chamness GC, Chang JC, Osborne CK, Rimawi MF, Schiff R. Upregulation of ER signaling as an adaptive mechanism of cell survivalin HER2-positive breast tumors treated with anti-HER2 therapy. Clin Cancer Res 2015;21(17):3995-4003.

8. Vici P, Pizzuti L, Sperduti I, Frassoldati A, Natoli C, Gamucci T, Tomao S, Michelotti A, Moscetti L, Gori S, Baldini E, Giotta F, Cassano A, Santini D, Giannarelli D, Di Lauro L, Corsi DC, Marchetti P, Sini V, Sergi $D$, Barba M, Maugeri-Saccà M, Russillo M, Mentuccia L, D'Onofrio L, lezzi L, Scinto AF, Da Ros L, Bertolini I, Basile ML, Rossi V, De Maria $\mathrm{R}$, Montemurro F. "Triple positive" early breast cancer: an observational multicenter retrospective analysis of outcome. Oncotarget 2016;7(14):17932-44.

9. NCCN. Breast Cancer Guidelines, Ver. 1.2018. (2018). Available from: www.nccn.org (Accessed: March 20, 2018).

10. Giordano SH, Temin S, Kirshner JJ, Chandarlapaty S, Crews JR, Davidson NE, Esteva FJ, Gonzalez-Angulo AM, Krop I, Levinson J, Lin NU, Modi S, Patt DA, Perez EA, Perlmutter J, Ramakrishna N, Winer EP; American Society of Clinical Oncology. Systemic therapy for patients with advanced human epidermal growth factor receptor 2-positive breast cancer: American society of clinical oncology clinical practice guideline. J Clin Oncol 2014;32(19):2078-99.

11. Larionov AA. Current Therapies for Human Epidermal Growth Factor Receptor 2-Positive Metastatic Breast Cancer Patients. Front Oncol 2018;8:89.

12. Colleoni $M$, Sun $Z$, Price KN, Karlsson P, Forbes JF, Thürlimann $B$, Gianni L, Castiglione M, Gelber RD, Coates AS, Goldhirsch A. Annual 
Hazard Rates of Recurrence for Breast Cancer During 24 Years of Follow-Up: Results From the International Breast Cancer Study Group Trials I to V. J Clin Oncol 2016;34:927-35.

13. Harvey JM, Clark GM, Osborne CK, Allred DC. Estrogen receptor status by immunohistochemistry is superior to the ligand-binding assay for predicting response to adjuvant endocrine therapy in breast cancer. J Clin Oncol 1999;17:1474-81.

14. Pertschuk LP, Kim DS, Nayer K, Feldman JG, Eisenberg KB, Carter AC, Rong ZT, Thelmo WL, Fleisher J, Greene GL.Immunocytochemica estrogen and progestin receptor assays in breast cancer with monoclonal antibodies. Histopathologic, demographic, and biochemical correlations and relationship to endocrine response and survival. Cancer 1990;66:1663-70.

15. Bartlett JM, Brookes CL, Robson T, van de Velde CJ, Billingham LJ, Campbell FM, Grant M, Hasenburg A, Hille ET, Kay C, Kieback DG, Putter H, Markopoulos C, Kranenbarg EM, Mallon EA, Dirix L, Seynaeve C, Rea D. Estrogen receptor and progesterone receptor as predictive biomarkers of response to endocrine therapy: a prospectively powered pathology study in the Tamoxifen and Exemestane Adjuvant Multinational trial. J Clin Oncol 2011;29:1531-38.

16. Colzani E, Liljegren A, Johansson AL, Adolfsson J, Hellborg H, Hall PF Czene K. Prognosis of patients with breast cancer: causes of death and effects of time since diagnosis, age, and tumor characteristics. J Clin Oncol 2011;29:4014-21.

17. Pogue-Geile KL, Song N, Jeong JH, Gavin PG, Kim SR, Blackmon NL, Finnigan M, Rastogi P, Fehrenbacher L, Mamounas EP, Swain SM, Wickerham DL, Geyer CE Jr, Costantino JP, Wolmark N, Paik S. Intrinsic subtypes, PIK3CA mutation, and the degree of benefit from adjuvant trastuzumab in the NSABP B-31 trial. J Clin Oncol 2015;33(12):1340 47

18. Perez EA, Ballman KV, Mashadi-Hossein A, Tenner KS, Kachergus JM, Norton N, Necela BM, Carr JM, Ferree S, Perou CM, Baehner F, Cheang MC, Thompson EA. Intrinsic subtype and therapeutic response among HER2-positive breast tumors from the NCCTG (Alliance) N9831 trial. J Natl Cancer Inst 2017;109(2).

19. Colleoni M, Bagnardi V, Rotmensz N, Gelber RD, Viale G, Pruneri G Veronesi P, Torrisi R, Cardillo A, Montagna E, Campagnoli E, Luini A, Intra M, Galimberti V, Scarano E, Peruzzotti G, Goldhirsch A. Increasing steroid hormone receptors expression defines breas cancer subtypes non responsive to preoperative chemotherapy. Breast Cancer Res Treat 2009;116(2):359-69.

20. Howlader N, Cronin KA, Kurian AW, Andridge R. Differences in breast cancer survival by molecular subtypes in the United States. Cancer Epidemiol Biomarkers Prev 2018,27(6):619-26. doi: 10.1158/1055 9965

21. Vaz-Luis I, Ottesen RA, Hughes ME, Marcom PK, Moy B, Rugo HS, Theriault RL, Wilson J, Niland JC, Weeks JC, Lin NU. Impact of hormone receptor status on patterns of recurrence and clinical outcomes among patients with human epidermal growth factor-2-positive breast cancer in the National Comprehensive Cancer Network: a prospective cohort study. Breast Cancer Res 2012,14(5):R129.

22. Chumsri S, Li Z, Serie DJ, Mashadi-Hossein A, Otero G, Song N, Pogue-Geile K, Gavin P, Paik S, Moreno-Aspitia A, Perez E, Thompson EA. Abstract PD3-02: Incidence of late relapse in HER2-positive (HER2+) breast cancer patients receiving adjuvant trastuzumab: Combined analysis of NCCTG (Alliance) N9831 and NSABP (NRG) B31. Cancer Res 2019;79(S4):PD3-02.

23. Swain SM, Baselga J, Kim SB, Ro J, Semiglazov V, Campone M, Ciruelos E, Ferrero JM, Schneeweiss A, Heeson S, Clark E, Ross G, Benyunes MC, Cortés J; CLEOPATRA Study Group. Pertuzumab, trastuzumab and docetaxel in HER2-pozitive metastatic breast cancer. N Engl J Med 2015;372(8):724-34

24. Vici P, Pizzuti L, Natoli C, Gamucci T, Di Lauro L, Barba M, Sergi D, Bott C, Michelotti A, Moscetti L, Mariani L, Izzo F, D'Onofrio L, Sperduti I, Conti F, Rossi V, Cassano A, Maugeri-Saccà M, Mottolese M, Marchetti P. Triple positive breast cancer: a distinct subtype? Cancer Treat Rev 2015;41(2):69-76

25. Loi S, Dafni U, Karlis D, Polydoropoulou V, Young BM, Willis S, Long B, de Azambuja E, Sotiriou C, Viale G, Rüschoff J, Piccart MJ, Dowsett $M$, Michiels S, Leyland-Jones B. Effects of estrogen receptor and human epidermal growth factor receptor-2 levels on the efficacy of trastuzumab: a secondary analysis of the HERA trial. JAMA Oncology 2016;2(8):1040-7.
26. Harbeck N. Neoadjuvant treatment of HER2-positive breast cancer: should therapy differ based on hormone receptor status? Ther Adv Med Oncol 2018;10:1-3.

27. Prat A, De Angelis C, Pascual T, Gutierrez C, Llombart-Cussac A, Wang T, Cortes J, Rexer BN, Veeraraghavan J, Forero-Torres A, Wolff AC, Morales S, Krop IE, Pavlick AC, Bermejo B, Hilsenbeck SG, Oliveira M, Schiff R, Osborne CK, Rimawi MF. HER2-enriched subtype and ERBB2 mRNA as predictors of pathological complete response following trastuzumab and lapatinib without chemotherapy in early-stage HER2-positive breast cancer: A combined analysis of TBCRC006/023 and PAMELA trials. J Clin Oncol 2018;36(15):509.

28. Harbeck N, Gluz O, Christgen M, Kates RE, Braun M, Küemmel S Schumacher C, Potenberg J, Kraemer S, Kleine-Tebbe A, Augustin D, Aktas B, Forstbauer H, Tio J, von Schumann R, Liedtke C, Grischke EM, Schumacher J, Wuerstlein R, Kreipe HH, Nitz UA. De-escalation strategies in human epidermal growth factor receptor 2 (HER2)-positive early breast cancer (BC): final analysis of the west german study group adjuvant dynamic marker-adjusted personalized therapy trial optimizing risk assessment and therapy response prediction in early BC HER2-and hormone receptor-positive phase II randomized trial-efficacy, safety, and predictive markers for 12 weeks of neoadjuvant trastuzumab emtansine with or without endocrine therapy (ET) versus trastuzumab Plus ET. J Clin Oncol 2017;35(26):3046-54.

29. Untch M, von Minckwitz G, Gerber B, Schem C, Rezai M, Fasching PA, Tesch H, Eggemann H, Hanusch C, Huober J, Solbach C, Jackisch C, Kunz G, Blohmer JU, Hauschild M, Fehm T, Nekljudova V, Loibl S; GBG and the AGO-B Study Group.Survival Analysis After Neoadjuvant Chemotherapy With Trastuzumab or Lapatinib in Patients With Human Epidermal Growth Factor Receptor 2-Positive Breast Cancer in the GeparQuinto (G5) Study (GBG 44). J Clin Oncol 2018;36(13):1308-16

30. Nahta R, O'Regan RM. Therapeutic implications of estrogen receptor signaling in HER2-positive breast cancers. Breast Cancer Res Treat 2012;135(1):39-48

31. Guarneri V, Dieci MV, Bisagni G, Frassoldati A, Bianchi GV, De Salvo GL, Orvieto E, Urso L, Pascual T, Paré L, Galván P, Ambroggi M, Giorgi CA, Moretti G, Griguolo G, Vicini R, Prat A, Conte PF. De-escalated therapy for HR+/HER2+ breast cancer patients with Ki67 response af ter 2 weeks letrozole: results of the PerELISA neoadjuvant study. Ann Oncol 2019,30(6): 921-6.

32. Regan MM, Fleming GF, Walley B, Francis PA, Pagani O. Adjuvant Systemic Treatment of Premenopausal Women With Hormone Receptor-Positive Early Breast Cancer: Lights and Shadows. J Clin Oncol 2019;37(11):862-6

33. Lambertini $M$, Campbell $C$, Bines J, Korde LA, Izquierdo M, Fumagalli D, Del Mastro L, Ignatiadis M, Pritchard K, Wolff AC, Jackisch C, Lang I, Untch M, Smith I, Boyle F, Xu B, Barrios CH, Baselga J, MorenoAspitia A, Piccart M, Gelber RD, de Azambuja E. Adjuvant anti-HER2 therapy, treatment-related amenorrhea, and survival in premenopausal HER2-positive early breast cancer patients. J Natl Cancer Inst 2019;111(1):86-94.

34. von Minckwitz G, Huang CS, Mano MS, Loibl S, Mamounas EP, Untch M, Wolmark N, Rastogi P, Schneeweiss A, Redondo A, Fischer $\mathrm{HH}$ Jacot W, Conlin AK, Arce-Salinas C, Wapnir IL, Jackisch C, DiGiovanna MP, Fasching PA, Crown JP, Wülfing P, Shao Z, Rota Caremoli E, Wu H, Lam LH, Tesarowski D, Smitt M, Douthwaite H, Singel SM, Geyer CE Jr; KATHERINE Investigators. Trastuzumab emtansine for residual invasive HER2-positive breast cancer. N Engl J Med 2019;380(7):61728.

35. Martin M, Holmes FA, Ejlertsen $B$, Delaloge $S$, Moy $B$, Iwata $H$, von Minckwitz G, Chia SKL, Mansi J, Barrios CH, Gnant M, Tomašević Z, Denduluri N, Šeparović R, Gokmen E, Bashford A, Ruiz Borrego M Kim SB, Jakobsen EH, Ciceniene A, Inoue K, Overkamp F, Heijns JB, Armstrong AC, Link JS, Joy AA, Bryce R, Wong A, Moran S, Yao B, Xu F, Auerbach A, Buyse M, Chan A; ExteNET Study Group. Neratinib after trastuzumab-based adjuvant therapy in HER2-positive breast cancer (ExteNET): 5-year analysis of a randomised, double-blind, placebocontrolled, phase 3 trial. Lancet Oncol 2017;18(12):1688-700.

36. Tolaney SM, Barry WT, Guo H, Dillon D, Dang CT, Yardley DA, Moy B, Marcom PK, Albain KS, Rugo HS, Ellis MJ, Shapira J, Wolff AC, Carey LA, Overmoyer B, Partridge AH, Hudis CA, Krop IE, Burstein HJ, Winer EP. Seven-year (yr) follow-up of adjuvant paclitaxel $(T)$ and trastuzumab (H) (APT trial) for node-negative, HER2-positive breast cancer 
(BC). J Clin Oncol 2017;35(15):511-511. doi: 10.1200/JCO.2017.35.15 suppl.511

37. Kaufman B, Mackey JR, Clemens MR, Bapsy PP, Vaid A, Wardley A, Tjulandin S, Jahn M, Lehle M, Feyereislova A, Révil C, Jones A. Trastuzumab plus anastrozole versus anastrozole alone for the treatment of postmenopausal women with human epidermal growth factor receptor 2-positive, hormone receptor-positive metastatic breast cancer: results from the randomized phase III TAnDEM study. J Clin Oncol 2009;27(33):5529-37.

38. Johnston S, Pippen J Jr, Pivot $X$, Lichinitser M, Sadeghi S, Dieras V, Gomez HL, Romieu G, Manikhas A, Kennedy MJ, Press MF, Maltzman J, Florance A, O'Rourke L, Oliva C, Stein S, Pegram M. Lapatinib combined with letrozole versus letrozole and placebo as first-line therapy for postmenopausal hormone receptor-positive metastatic breast cancer. J Clin Oncol 2009;27(33):5538-46.

39. Schwartzberg LS, Franco SX, Florance A, O'Rourke L, Maltzman J, Johnston S. Lapatinib plus letrozole as first-line therapy for HER-2+ hormone receptor-positive metastatic breast cancer. Oncologist 2010;15(2):122-9.

40. Huober J, Fasching PA, Barsoum M, Petruzelka L, Wallwiener D, Thomssen C, Reimer T, Paepke S, Azim HA, Ragosch V, Kubista E, Baumgärtner AK, Beckmann MW, May C, Nimmrich I, Harbeck N. Higher efficacy of letrozole in combination with trastuzumab compared to letrozole monotherapy as first-line treatment in patients with HER2-positive, hormone-receptor-positive metastatic breast cancer - results of the eLEcTRA trial. Breast 2012;21(1):27-33.

41. Hayashi N, Niikura N, Yamauchi H, Nakamura S, Ueno NT. Adding hormonal therapy to chemotherapy and trastuzumab improves prognosis in patients with hormone receptor-positive and human epidermal growth factor receptor 2-positive primary breast cancer. Breast Cancer Res Treat 2013;137(2):523-31.

42. Cardoso F, Costa A, Senkus E, Aapro M, André F, Barrios CH, Bergh J, Bhattacharyya G, Biganzoli L, Cardoso MJ, Carey L, CorneliussenJames D, Curigliano G, Dieras V, El Saghir N, Eniu A, Fallowfield L, Fenech D, Francis $P$, Gelmon K, Gennari A, Harbeck N, Hudis C, Kaufman B, Krop I, Mayer M, Meijer H, Mertz S, Ohno S, Pagani O, Papadopoulos E, Peccatori F, Penault-Llorca F, Piccart MJ, Pierga JY, Rugo H, Shockney L, Sledge G, Swain S, Thomssen C, Tutt A, Vorobiof D, Xu B, Norton L, Winer E. 3rd ESO-ESMO international consensus guidelines for advanced breast cancer (ABC 3). Ann Oncol 2017;28(1):16-33.

43. Arpino G, Ferrero JM, De la Haba-Rodriguez J, Easton V, Schuhmacher C, Restuccia E, Rimawi M. Primary analysis of PERTAIN: a randomized, two-arm, open-label, multicenter phase II trial assessing the efficacy and safety of pertuzumab given in combination with trastuzumab plus an aromatase inhibitor in first-line patients with HER2-positive and hormone receptor-positive metastatic or locally advanced breast cancer. Cancer Res 2017;77(4 Suppl):S3-04.

44. Gradishar WJ, Hegg R, Im SA, Park IH, Tjulandin S, Kenny S, Sarp S, Williams L, Izquierdo MA, Johnston SRD. Phase III study of lapatinib (L) plus trastuzumab ( $\mathrm{T}$ ) and aromatase inhibitor (Al) vs $\mathrm{T}+\mathrm{Al}$ vs $\mathrm{L}+\mathrm{Al}$ in postmenopausal women (PMW) with HER2+, HR+ metastatic breast cancer (MBC): ALTERNATIVE. J Clin Oncol 2017;35(15):1004.

45. Melichar B, Študentová H, Kalábová H, Vitásková D, Čermáková $P$, Hornychová $H$, Ryška A. Predictive and prognostic significance of tumor-infiltrating lymphocytes in patients with breast cancer treated with neoadjuvant systemic therapy. Anticancer Research 2014:34:1115-26.

46. Salgado R, Denkert C, Campbell C, Savas P, Nuciforo P, Aura C, de Azambuja E, Eidtmann H, Ellis CE, Baselga J, Piccart-Gebhart MJ, Michiels S, Bradbury I, Sotiriou C, Loi S. Tumor-infiltrating lymphocytes and associations with pathological complete response and event-free survival in HER2-positive early-stage breast cancer treated with lapatinib and trastuzumab: a secondary analysis of the NeoALTTO trial. JAMA Oncol 2015;1(4):448-54.

47. Bianchini G, Pusztai L, Pienkowski T, Im YH, Bianchi GV, Tseng LM, Liu MC, Lluch A, Galeota E, Magazzù D, de la Haba-Rodríguez J, Oh DY, Poirier B, Pedrini JL, Semiglazov V, Valagussa P, Gianni L. Immune modulation of pathologic complete response after neo- adjuvant HER2-directed therapies in the NeoSphere trial. Ann Oncol 2015;26(12):2429-36.

48. Solinas C, Ceppi M, Lambertini M, Scartozzi M, Buisseret L, Garaud S, Fumagalli D, de Azambuja E, Salgado R, Sotiriou C, Willard-Gallo K, Ignatiadis M. Tumor-infiltrating lymphocytes in patients with HER2positive breast cancer treated with neoadjuvant chemotherapy plus trastuzumab, lapatinib or their combination: a meta-analysis of randomized controlled trials. Cancer Treat Rev 2017:57:8-15.

49. Luen SJ, Salgado R, Fox S, Savas P, Eng-Wong J, Clark E, Kiermaier A, Swain SM, Baselga J, Michiels S, Loi S. Tumour-infiltrating lymphocytes in advanced HER2-positive breast cancer treated with pertuzumab or placebo in addition to trastuzumab and docetaxel: a retrospective analysis of the CLEOPATRA study. Lancet Oncol 2017;18:52-62.

50. Loi S, Giobbe-Hurder A, Gombos A, Bachelot T, Hui R, Curigliano G, Campone M, Biganzoli L, Bonnefoi $H$, Jerusalem $G$, Bartsch R, Rabaglio-Poretti M, Kammler R, Maibach R, Smyth MJ, Di Leo A, Colleoni M, Viale G, Regan MM, Andre F. Abstract GS2-06: Phase Ib/ll study evaluating safety and efficacy of pembrolizumab and trastuzumab in patients with trastuzumab-resistant HER2-positive metastatic breast cancer: Results from the PANACEA (IBCSG 45-13/ BIG 4-13/KEYNOTE-014) study. Cancer Res 2018;78(4 Suppl):GS2-06.

51. Dieci MV, Prat A, Tagliafico E, Paré L, Ficarra G, Bisagni G, Piacentini F, Generali DG, Conte P, Guarneri V. Integrated evaluation of PAM50 subtypes and immune modulation of pCR in HER2-positive breast cancer patients treated with chemotherapy and HER2-targeted agents in the CherLOB trial. Ann Oncol 2016;27(10):1867-73.

52. Nuciforo P, Pascual T, Cortés J, Llombart-Cussac A, Fasani R, Paré L, Oliveira M, Galvan P, Martínez N, Bermejo B, Vidal M, Pernas S, López R, Muñoz M, Garau I, Manso L, Alarcón J, Martínez E, RodrikOutmezguine V, Brase JC, Villagrasa P, Prat A, Holgado E. A predictive model of pathological response based on tumor cellularity and tumor-infiltrating lymphocytes (CelTIL) in HER2-positive breast cancer treated with chemo-free dual HER2 blockade. Ann Oncol 2018;29(1):170-7.

53. Pernas S, Tolaney SM, Winer EP, Goel S. CDK4/6 inhibition in breast cancer: current practice and future directions. Ther Adv Med Oncol 2018;10:1-15.

54. Ciruelos E, Villagrasa P, Paré L, Oliveira M, Pernas S, Cortés J, Soberino J, Adamo B, Vazquez S, Martínez N, Perelló A, Bermejo B, Martínez E, Garau I, Melé M, Morales S, Galván P, Pascual T, Canes J, Nuciforo P, Gonzalez X, Prat A. Abstract PD3-03: SOLTI-1303 PATRICIA phase II trial (STAGE 1)-Palbociclib and trastuzumab in postmenopausal patients with HER2-positive metastatic breast cancer. Cancer Res 2019;79(4 Suppl):PD3-03.

55. Gianni L, Bisagni G, Colleoni M, Del Mastro L, Zamagni C, Mansutti M, Zambetti M, Frassoldati A, De Fato R, Valagussa P, Viale G. Neoadjuvant treatment with trastuzumab and pertuzumab plus palbociclib and fulvestrant in HER2-positive, ER-positive breast cancer (NA-PHER2): an exploratory, open-label, phase 2 study. Lancet Oncol 2018;19(2):249-56.

56. Pernas S, Tolaney SM. HER2-positive breast cancer: new therapeutic frontiers and overcoming resistance. Ther Adv Med Oncol 2019;19(11):1-16.

57. André F, Hurvitz S, Fasolo A, Tseng LM, Jerusalem G, Wilks S, O'Regan R, Isaacs C, Toi M, Burris H, He W, Robinson D, Riester M, Taran T, Chen D, Slamon D. Molecular alterations and everolimus efficacy in human epidermal growth factor receptor 2-overexpressing metastatic breast cancers: combined exploratory biomarker analysis from BOLERO-1 and BOLERO-3. J Clin Oncol 2016;34(18):2115-24.

58. Sirohi B, Rastogi S, Dawood S. Buparlisib in breast cancer. Future Oncol 2015;11(10):1463-70.

59. Jain S, Nye L, Santa-Maria C, Bontemps L, Williams A, Garrett H, Dammrich E, Giles F, Gradishar W. Abstract P6-13-11: Phase I study of alpelisib and T-DM1 in trastuzumab-refractory HER2-positive metastatic breast cancer. Cancer Res 2016;76(4 Suppl):P6-13-11.

60. Melichar, B. Laboratory medicine and medical oncology: the tale of two Cinderellas. Clin Chem Lab Med 2013;51(1):99-112. 